\title{
Continuous Primary Beer Fermentation with Brewing Yeast Immobilized on Spent Grains
}

\author{
Tomáš Brányik ${ }^{1}$, António Vicente ${ }^{1}$, José Machado Cruz $^{2}$ and José Teixeira ${ }^{1,3}$
}

\begin{abstract}
J. Inst. Brew. 108(4), 410-415, 2002

This work demonstrated the technological feasibility of the three-phase airlift bioreactor (ALR) with brewing yeast immobilized on spent grains (a brewing by-product) for continuous beer production. The optimum fermentation performance of the one stage immobilized cell bioreactor was achieved at residence times between 18-25 h (dilution rate $0.04-0.055 \mathrm{~h}^{-1}$ ) and was characterized by an apparent degree of attenuation in the range of $70-80 \%$. The productivity of the system in terms of ethanol concentration in green beer (ca. $4.2 \%$ ) was satisfactory. Although the diacetyl concentration in the young beer was high $(0.32 \mathrm{mg}$ $\mathrm{L}^{-1}$ at $\mathrm{D}=0.04 \mathrm{~h}^{-1}$ ) it is speculated that the level could be reduced by cell growth control, aeration and temperature optimisation. The immobilized yeast fermentation in the ALR was shown to be robust in recovery after process upsets.
\end{abstract}

Key words: Beer, continuous, immobilized, fermentation, spent grains, yeast.

\section{INTRODUCTION}

Various new technical, biochemical and microbiological discoveries have found application in the brewing industry during the last few decades. They are mostly used in order to achieve cost and productivity advantages in the process plant. However, traditional beer fermentation carried out as a batch process has economical limitations resulting from its energy and time consuming character. The next step in the wort fermentation improvement is considered to be a fully continuous process ${ }^{15}$.

Although the advantages of a continuous fermentation process were recognized early, there are still only a few continuous brewing processes in successful operation worldwide ${ }^{7}$. The reasons why continuous systems with immobilized yeasts have not yet become adopted in the brewing industry include increased complexity of operations compared to batch process, flavour problems, risk of contamination, yeast viability, carrier price and the inconvenience of immobilization ${ }^{14}$.

Matrices most commonly used for yeast immobiliza-

\footnotetext{
${ }^{1}$ Centro de Engenharia Biológica - IBQF, Universidade do Minho, Campus de Gualtar, 4710-057 Braga, Portugal

${ }^{2}$ UNICER - União Cervejeira S.A., Leça do Balio, 4466-955 S. Mamede de Infesta, Portugal

${ }^{3}$ Corresponding author. Email: jateixeira@deb.uminho.pt
}

Publication no. G-2002-1216-002

(C) 2002 The Institute \& Guild of Brewing tion include gel type materials such as alginate, calcium pectate and carrageenan ${ }^{5}$, porous structures namely glass beads, silicon carbide and gluten pellets ${ }^{17,18,22}$ and cellulose based materials ${ }^{10,11,22}$. Among the latter, DEAE-cellulose and wood chips have been used in full scale processes. Nevertheless, the need for an inexpensive and regenerable support material for continuous beer fermentation is still relevant.

As previously shown ${ }^{4}$ the cellulose based carrier obtained from spent grains can be considered as a promising alternative to other support materials. From an economic viewpoint, the spent grains are very advantageous taking into account their brewing by-product origin and simple preparation process. Further, they meet the requirements of high cell load, stability, food grade and the possibility to regenerate and sterilize. Moreover, the yeast biomass surrounding the non-porous surface of the spent grains is in direct contact with the bulk liquid, thus reducing mass transfer problems associated with other immobilized systems ${ }^{13}$.

In addition to the carrier material, the bioreactor design will also markedly influence the final success of the proposed technology. The choice of an airlift reactor for the immobilized system used in this work is aligned with the latest trends in continuous brewing. Compared to packedbed reactors, the systems with pneumatically forced circulation offer the advantage of improved $\mathrm{CO}_{2}$ removal, no channelling and clogging, and better mass and heat transfer $^{12}$.

The present article deals with continuous primary beer fermentation in an airlift reactor containing brewing yeast immobilized on spent grains. Wort feed rate was studied in terms of bioreactor performance and diacetyl formation.

\section{MATERIALS AND METHODS}

\section{Yeast strain and culture conditions}

The brewing yeast Saccharomyces uvarum (carlsbergensis) was supplied by the brewing company UNICER, $\mathrm{SA}$. The yeast for inoculation of the continuous airlift reactor were cultivated in $500 \mathrm{~mL}$ of synthetic medium under aerobic conditions on a rotary shaker $(120 \mathrm{rpm})$ at $30^{\circ} \mathrm{C}$ for $30 \mathrm{~h}$. The composition of the synthetic medium was as follows $\left(\mathrm{g} \mathrm{L}^{-1}\right): \mathrm{KH}_{2} \mathrm{PO}_{4}, 5.0 ;\left(\mathrm{NH}_{4}\right)_{2} \mathrm{SO}_{4}, 2.0$; $\mathrm{MgSO}_{4} \cdot 7 \mathrm{H}_{2} \mathrm{O}, 0.4$; yeast extract, 1.0 ; glucose, 10.0 . Medium with the same composition was used in continuous experiments during biomass attachment. The all malt wort used in this work had an original gravity of $13^{\circ} \mathrm{P}$ and was supplied by UNICER, SA. 


\section{Carrier preparation}

Dry spent grains $(100 \mathrm{~g})$ were mixed in $1500 \mathrm{~mL}$ of 3 vol $\% \mathrm{HCl}$ solution at $60^{\circ} \mathrm{C}$ for $2.5 \mathrm{~h}$ to hydrolyse the residual starchy endosperm and embryo of the barley kernel present in the spent grains. Then the mixture was cooled, washed with water and dried. The remaining solids (ca. 30 g), mainly the husks of the barley grain, were partially delignified by shaking $(120 \mathrm{rpm})$ in $500 \mathrm{~mL}$ of $2 \%$ (wt/ vol) $\mathrm{NaOH}$ solution at $30^{\circ} \mathrm{C}$ for $24 \mathrm{~h}$. After being washed several times with water (until neutral $\mathrm{pH}$ ) and dried, the carrier (ca. $10 \mathrm{~g}$ ) was ready to be used. The preparation procedure gave a $10 \%$ yield from dry spent grains. The drying steps applied in the preparation procedure were necessary only to quantify the yields.

\section{Airlift reactor (ALR)}

The ALR used in this work is of the concentric draught tube type with an enlarged top section for degassing and a total working volume of $6 \mathrm{~L}$. The dimensions of the reactor are: total height $-90 \mathrm{~cm}$; down comer's length -60 $\mathrm{cm}$, inside diameter $-7 \mathrm{~cm}$; draught tube length $-56 \mathrm{~cm}$, diameter $-3.2 \mathrm{~cm}$, thickness $-4 \mathrm{~mm}$; cylindrical part's length $-14.5 \mathrm{~cm}$, diameter $-19.2 \mathrm{~cm}$. The angle between the conical sector and the main body was $51^{\circ}$. Air injection was through a perforated plate with 7 holes, each of 1 $\mathrm{mm}$ diameter, placed $2.5 \mathrm{~cm}$ below the annulus of the riser. The outflow of the reactor was placed behind a sedimentation barrier thus minimizing carrier losses. The temperature inside the reactor $\left(12.5^{\circ} \mathrm{C}\right)$ was maintained by means of a cooling coil connected to a refrigeration bath. Air flow rate of $0.8 \mathrm{~L} \mathrm{~min}^{-1}$ was applied to ensure solid phase circulation and was kept constant using a mass flow controller (Hastings 202D, Hastings Instruments, USA).

\section{ALR system start-up}

The Plexiglas ALR reactor was sterilized using sodium hypochlorite solution ( $2 \%$ active chlorine) at least 4 days prior to fermentation. After draining the reactor the sterile air supply was started and the reactor was filled with the sterilized slurry consisting of spent grains (120 g dry state) in distilled water $(3 \mathrm{~L})$. Prior to inoculation, the reactor containing fresh carrier was washed with $50 \mathrm{~L}$ of sterile water. Subsequently, the reactor was charged with concentrated medium to obtain the desired concentration of the synthetic medium and then inoculated with $1 \mathrm{~L}$ of yeast cell suspension grown using a rotary shaker. At the end of $24 \mathrm{~h}$ batch growth, the feed of synthetic medium was started and it took approximately 7 days at $\mathrm{D}=0.2 \mathrm{~h}^{-1}$ to reach a sufficiently high immobilized biomass load (min.

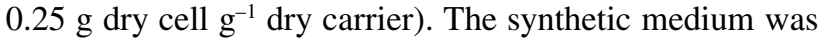
then changed to sterilized wort and the continuous system was considered to be in steady state conditions after a period of 5 residence times.

\section{Bubble column reactor}

Experiments with yeast immobilization, in wort and in the synthetic medium, were carried out in a continuous bubble column reactor with a total working volume of 440 $\mathrm{mL}$. The carrier (6-7 g dry weight) was placed in the reactor with wort or the synthetic medium $\left(10 \mathrm{~g} \mathrm{~L}^{-1}\right.$ glucose $)$ and inoculated with $100 \mathrm{~mL}$ of pre-cultured brewing yeast suspension. The continuous feed started after $16 \mathrm{~h}$ of batch growth. The medium was supplied at the bottom of the reactor by means of a peristaltic pump (101U/R, WatsonMarlow, England). The bubble column was constantly aerated with $0.9 \mathrm{~L} \mathrm{~min}^{-1}$ of sterile air. The reactor outlet was connected to an overflow.

\section{Green beer analysis}

Characterization of wort and green beer (specific gravity, original extract, alcohol, $\mathrm{pH}$, colour) was performed by SCABA 5600 (Automatic Beer Analyser, Tecator AB, Sweden). Total diacetyl was determined by gas chromatographic analysis of the static headspace ${ }^{19}$ and free amino nitrogen (FAN) was measured according to the current European Brewery Convention recommended methods ${ }^{1}$.

\section{Immobilized biomass determination}

A sample containing approximately $1.0 \mathrm{~g}$ dry biocatalyst was taken from the reactor. The bulk liquid was removed with a syringe and the carrier was washed with 200 $\mathrm{mL}$ of distilled water. The carrier was filtered and washed with $400 \mathrm{~mL}$ of distilled water on a paper filter and dried at $105^{\circ} \mathrm{C}$ for $12 \mathrm{~h}$. An amount of approximately $0.5 \mathrm{~g}$ dry biocatalyst was weighed into an Erlenmeyer flask with $100 \mathrm{~mL}$ of $3 \%$ (wt/vol) $\mathrm{NaOH}$ solution and shaken at 120 rpm for $24 \mathrm{~h}$. During this time the attached biomass was completely removed from the carrier and this was verified using microscopy. The biomass free carrier was filtered and after being washed on the filter with $400 \mathrm{~mL}$ of distilled water it was dried at $105^{\circ} \mathrm{C}$ for $5 \mathrm{~h}$. The amount of yeast biofilm was determined from the weight difference before and after the treatment with caustic. Corrections of the biomass weight for the losses of carrier itself were carried out by blank experiments with clean carrier.

\section{Holocellulose determination}

The carrier, made of spent grains (ca. $5 \mathrm{~g}$ ), was soaked in water $(160 \mathrm{~mL})$. Acetic acid (10 drops) and sodium chlorite (1.5 g) was added and the mixture was kept at 80$90^{\circ} \mathrm{C}$ during $1 \mathrm{~h}$. The addition of acetic acid and sodium chlorite and heating was repeated three times. The white holocellulose, a combination of cellulose and hemicellulose, that was isolated was filtered, washed with water and acetone, and weighted after drying at $105^{\circ} \mathrm{C}$.

\section{RESULTS}

Microscopic observations from the beginning of the immobilization process revealed a non-homogeneous biomass distribution over the carrier surface, with local biomass accumulations confirming the existence of preferred attachment sites (Fig. 1A). Scanning electron microscopy ${ }^{8}$ (SEM) showed a wide age distribution of the attached brewing yeast (from budding cells to cells with several scars) and the absence of any polymer structures on the cell wall playing roles in cell adhesion (Fig. 1B). In addition to cell adhesion onto the spent grains, spatial retention of the yeast (i.e. adsorption) in various shelters (crevices, pores, tangled carrier particles) on the carrier surface enhanced local biomass accumulation (Fig. 1A). 
The immobilization of yeast onto spent grains in the airlift reactor was carried out by feeding with synthetic medium. Only after the immobilized biomass load reached the minimum value of $\mathrm{X}_{\mathrm{im}}=0.25 \mathrm{~g}$ dry cell $\mathrm{g}^{-1}$ dry carrier $\left(g_{\text {d.cell }} \mathrm{g}_{\text {d.c. }}\right)$ was the feeding of the reactor switched to wort. The start-up period of the reactor was characterised by high media consumption and the choice of the synthetic medium avoided difficulties with supply and storage of wort. Experiments in the bubble-column reactor illustrated that the attachment of brewing yeast onto spent grains occurred in brewery wort as the fermentation medium (Fig. 2). Although the onset of the yeast attachment in wort was delayed by ca. $24 \mathrm{~h}$ and the immobilized biomass load $\left(\mathrm{X}_{\mathrm{im}}\right)$ reached on average $25 \%$ lower values when compared to the synthetic medium, the immobilization under beer fermentation conditions was considered satisfactory.

The initial start-up period of the continuous experiments in the airlift reactor (ALR) where synthetic medium was used as a feed gave rise to the spontaneous attachment of brewing yeast to the surface of the spent grain particles. After a sufficient immobilized biomass load was obtained, approximately $0.3 \mathrm{~g}_{\text {d.cell }} \mathrm{g}^{-1}$ d.c. , the reactor feed was changed to wort ( 9 th day). This further increased the amount of immobilized biomass $\left(0.55 \mathrm{~g}_{\text {d.cell }} \mathrm{g}^{-1}\right.$ d.c. $)$. Simultaneously, the change to a fermentation medium with

A

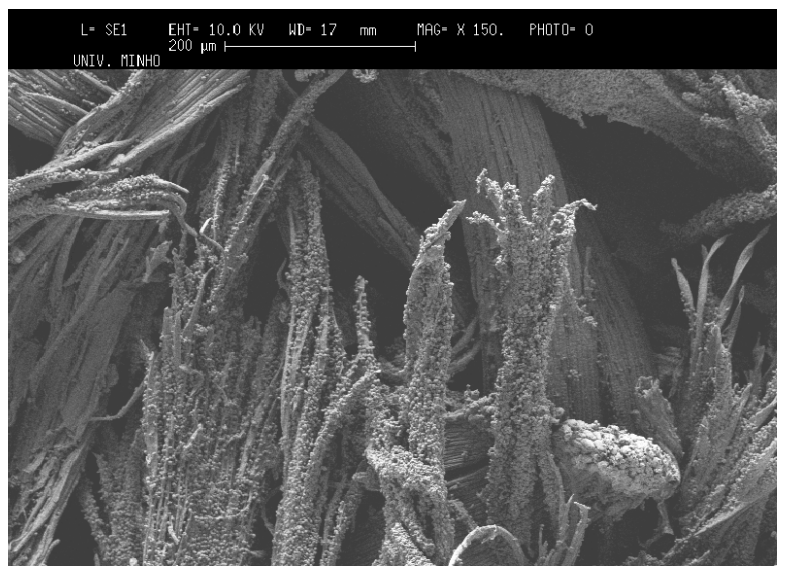

B

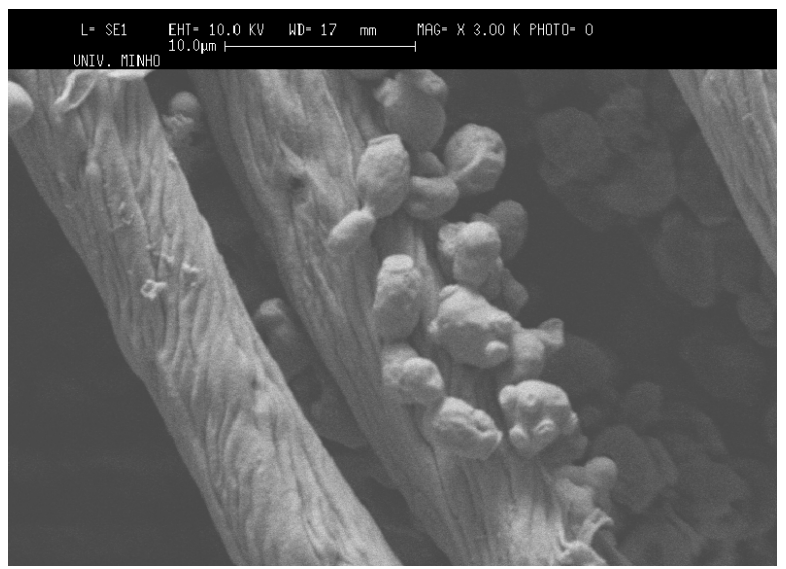

FIG. 1. Photomicrographs (SEM) of spent grains particles with a biomass load of $\mathrm{X}_{\mathrm{im}}=0.08 \mathrm{~g}_{\text {d.cell }} \mathrm{g}^{-1}$ d.c. $; \mathrm{A}-\times 150$ magnification / white bar represents $200 \mu \mathrm{m} ; \mathrm{B}-\times 3000$ magnification / white bar represents $10 \mu \mathrm{m}$. higher substrate concentration (i.e. wort) resulted in increased free biomass concentration (Fig. 3). The cell viability remained constant throughout the duration of the experiment showing no more than 3\% dead cells both among free and immobilized cells as determined by staining with methylene blue ${ }^{3}$.

On the 19th day of continuous fermentation a $12 \mathrm{~h}$ break in the air supply caused the carrier to settle to the bottom of the reactor and in order to re-establish circulation it was necessary to vigorously agitate the reactor. This mechanical stress together with the changed physiological conditions caused considerable release of the immobilized biomass, increasing temporarily the free biomass concentration in the outflow (Fig. 3). It took approximately one week to return the biomass balance in the ALR to a state comparable to before aeration failure.

The fermentation performance of the immobilized yeast bioreactor can be described using the values of apparent and real degree of attenuation. The optimal dilution

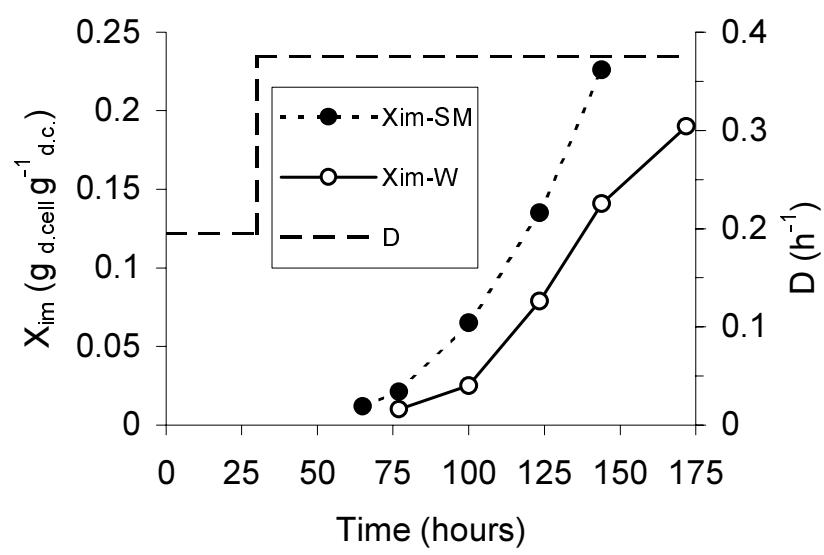

FIG. 2. Development of the immobilized yeast biofilm $X_{\text {im }}(g$ dry cell $\mathrm{g}^{-1}$ dry carrier) on the surface of spent grain in synthetic medium $\left(\mathrm{X}_{\mathrm{im}}-\mathrm{SM}\right)$ and wort $\left(\mathrm{X}_{\mathrm{im}}-\mathrm{W}\right)$ at a maximum dilution rate $\mathrm{D}=0.375 \mathrm{~h}^{-1}$.

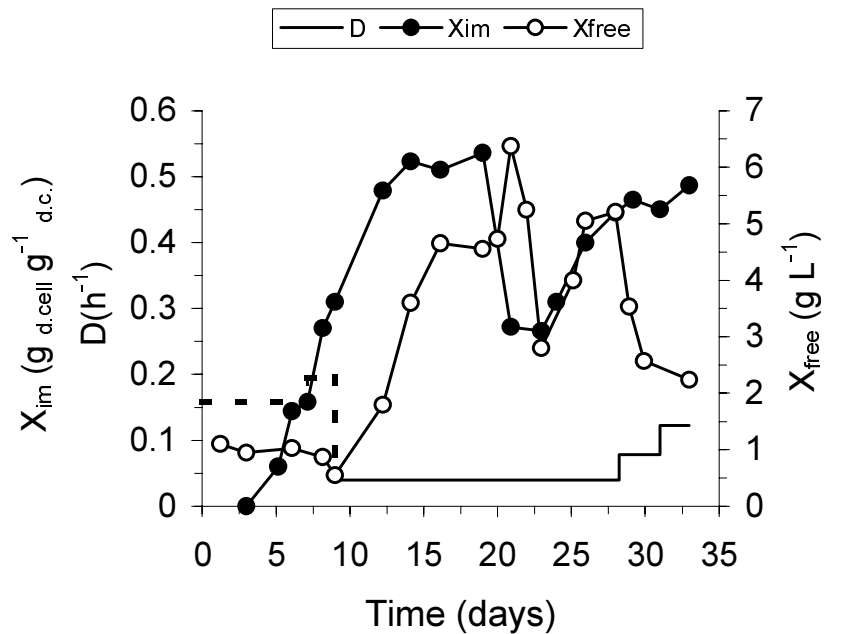

FIG. 3. Immobilized and free cell concentration during continuous main fermentation: $X_{\mathrm{im}}-$ immobilized biomass load $\left(\mathrm{g}_{\mathrm{d} . c e l l}\right.$ $\left.\mathrm{g}^{-1}{ }_{\text {d.c. }}\right) ; \mathrm{X}_{\text {free }}-$ free cell concentration $\left(\mathrm{g} \mathrm{l}^{-1}\right) ; \mathrm{D}$ - dilution rate of synthetic medium (dashed line) and wort (solid line). 


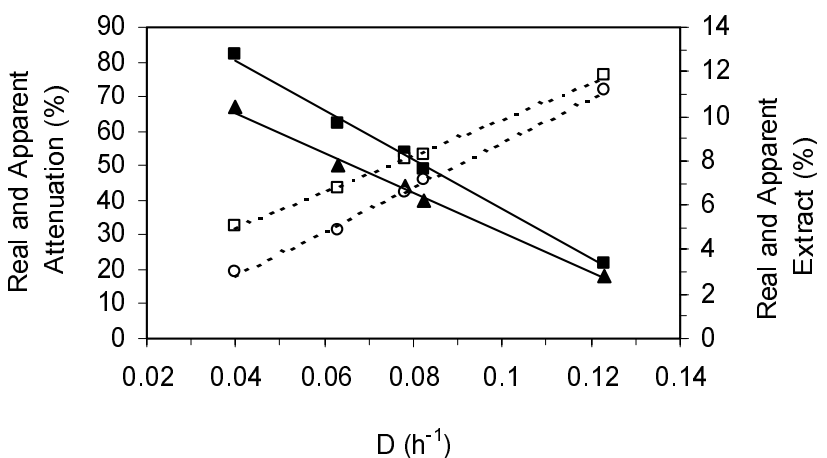

FIG. 4. The influence of the wort feed rate on selected parameters of the main fermentation: (solid triangle) - real attenuation $(\%)$; (solid square) - apparent attenuation (\%); (open square) real extract (\%); (open circle) - apparent extract (\%).

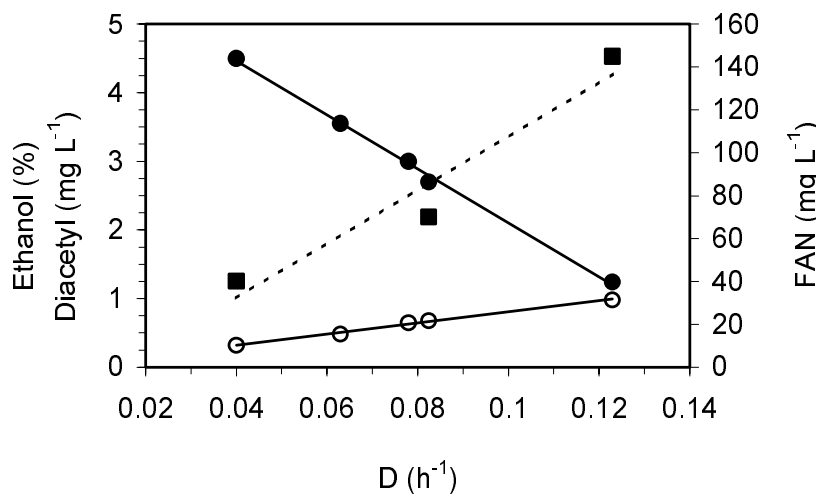

FIG. 5. The influence of the wort feed rate on selected parameters of the main fermentation: (closed circle) - ethanol (\%); (open circle) - diacetyl $\left(\mathrm{mg} \mathrm{L}^{-1}\right)$; (closed square) - free amino nitrogen $\left(\mathrm{mg} \mathrm{L}^{-1}\right)$.

rates (D) or residence times (RT) of the reactor were determined experimentally by variation of the wort feeding rate. The desired degree of apparent attenuation for stage one of primary beer fermentation, i.e. $70-80 \%$, was obtained in the range of D and RT of approximately $\mathrm{D}=$ $0.04-0.055 \mathrm{~h}^{-1}$ and RT $=18-25 \mathrm{~h}$, respectively (Fig. 4). At these feeding rates the apparent extract of the green beer was $3-4 \%$ (Fig. 4), and it contained ca. $10 \%$ of the initial fermentable sugars that could be used as substrate by the yeast during beer maturation.

In addition to the fermentable sugars consumed, there were several compounds produced during the main fermentation, which could strongly influence the flavour profile of the beer. At the degree of apparent attenuation of $70-80 \%$, the concentration of ethanol produced in the ALR was 3.8-4.5\% (Fig. 5). As a result of the intensive biomass growth in the ALR, high levels of diacetyl were measured in the entire range of D (Fig. 5). At the lowest studied D, the diacetyl concentration in the green beer was $0.32 \mathrm{mg} \mathrm{L}^{-1}$, a number significantly above the taste threshold in mature beer ${ }^{12}$. Another indicator of the excessive biomass growth in the ALR was the high free amino nitrogen (FAN) consumption. The initial concentration of FAN $(250 \mathrm{mg} / \mathrm{L})$ in wort decreased at $\mathrm{D}=0.04 \mathrm{~h}^{-1}$ to ca. $45 \mathrm{mg}$ $\mathrm{L}^{-1}$ (Fig. 5).

\section{DISCUSSION}

\section{Immobilization of brewing yeast onto the surface of spent grains}

Colonization of the cellulose based carrier particles consisting of spent grains occurs by two mechanisms: (i) spontaneous adhesion of yeast cells to "active sites" on the surface of the spent grains, and (ii) retention of yeast cells by the carrier's surface roughness. It is speculated that during the continuous experiment, spontaneous cell adhesion may have taken place. The carrier made of spentgrains, although containing approximately $90 \%$ holocellulose, was not chemically uniform and its surface properties cannot be considered homogeneous. Therefore, the contact between the surfaces of the spent grains with yeast surfaces may result in spontaneous and energetically advantageous interactions leading to stable cell adhesion. Yeast accumulation on spent grains is further supported by the carrier's surface roughness, which serves as a shelter for cells against the shear forces exerted by the turbulence in the reactor. Starting from initial cell adhesion and/or adsorption, the yeast gradually covered the entire surface of carrier particles with a yeast biofilm of variable thickness, reflecting the differences in the carrier's surface properties.

The lower yeast attachment rate onto spent grains in wort, in comparison to synthetic medium, may perhaps be explained by an intensified competition between cells and wort proteins (the concentration of proteins being higher in wort) for adhesion sites on the carrier surface. The adsorbed proteins form a hydrophilic layer on the cell interaction sites, thus attenuating yeast adhesion ${ }^{20}$.

\section{Immobilized biomass load}

Immobilized cell load is an important variable of the immobilized cell reactor systems. From the values of the immobilized and free biomass (Fig. 3) and the amount of carrier in the reactor (ca. $100 \mathrm{~g}$ of dry carrier) it appears that the ratio between immobilized cells and free cells in the reactor was approximately $1.7-2.0$ at the dilution rate $\mathrm{D}=0.04 \mathrm{~h}^{-1}$. This number is in agreement with the ratio reached in a two stage fluidised bed system ${ }^{18}$. At higher wort feed rates the immobilized/free cell ratio shifted to values between 2.8 and 3.0 due to a drop in the concentration of free cells caused by wash out, while the immobilized cell load remained either constant or exhibited a slight rise (Fig. 3).

Attempts to increase the proportion of immobilized cells by using more support material in the reactor resulted in intensive carrier wash out until an equilibrium carrier volume fraction of $1.5-1.8 \%$ (wt/vol) was formed, which corresponded to $90-105 \mathrm{~g}$ dry carrier per reactor volume. The swollen spent grains plus the additional fully developed yeast biofilm on the grain surface represented approximately $25 \mathrm{vol} \%$ of the solid fraction in the threephase ALR bioreactor. Further increases of carrier (solid) volume fraction above $2 \%$ (wt/vol) resulted in dead zones in the reactor due to insufficient liquid mixing. Important for the biocatalyst wash out was the dead zone located below the sedimentation barrier of the outflow. The lack of liquid mixing below the outflow resulted in the formation of floating clumps of biocatalyst particles. This was 
due to poor removal of $\mathrm{CO}_{2}$ gas bubbles. The floating biocatalyst was thus dragged, together with the medium, through the outflow. Significant carrier losses (0.5-1.0 g dry carrier $h^{-1}$ ) continued until the solid volume fraction decreased to the equilibrium carrier volume fraction ca. $1.5-1.8 \%$ (wt/vol) and at this stage the particle agglomeration and flotation diminished. Although accidental carrier wash out was observed during the entire continuous main fermentation, it was of little importance since the carrier could be repeatedly replaced during reactor operation.

Not surprisingly, natural cell adhesion and adsorption onto spent grains was sensitive to mechanical stress and changes in the reactor environment. Nevertheless, the continuous immobilized yeast bioreactor system proved that its self-regulatory ability overcame the adverse effect of process failures. Although long-term operational stability of the system was not studied, all continuous primary beer fermentations carried out during this work operated reliably for more than one month.

\section{Influence of the feed rate on main fermentation performance}

The efficiency (measured by degree of attenuation) and the productivity (in terms of hydraulic retention time) of the main beer fermentation in the ALR with yeast immobilized on spent grains was in the same range as published elsewhere ${ }^{16,18,21}$. Taking into consideration the original gravity of the wort used in this work $\left(13^{\circ} \mathrm{P}\right)$ it was not surprising that the ethanol concentration of the green beer produced by the ALR was somewhat higher than levels in studies published to date $\mathrm{e}^{5,10,16}$.

Biomass growth during fermentation is accompanied by accumulation of diacetyl, a compound that gives rise to an undesirable "buttery" flavour in the final product. Diacetyl is formed by spontaneous decarboxylation of $\alpha$ acetolactate, an intermediate of the valine-leucine biosynthetic pathway, and is subsequently re-assimilated by the yeast ${ }^{6}$. However, at short hydraulic residence times in continuous fermentation, the reduction of diacetyl and its precursor is not complete. As a consequence of this, biomass growth control by aeration rate and process temperature optimisation must be carried out and/or an accelerated diacetyl precursor conversion and maturation system applied $^{9}$ to decrease the diacetyl concentration in the final product to under the taste threshold in beer. It is speculated that air input, the driving force for circulation in the ALR, could to a large extent be replaced by $\mathrm{CO}_{2}$ to reduce excessive cell growth ${ }^{21}$.

Another indicator of the excessive biomass growth in the ALR was the high free amino nitrogen (FAN) consumption. Keeping in mind that the origin of the diacetyl precursor is in amino acid metabolism and that various intermediates and by-products of amino acid metabolism are important organoleptically, the high FAN (amino acid) uptake by yeast has significance.

The one stage process described in this paper can be replaced by a two or multi stage system where the cell growth and substrate metabolism take place in distinct reactors thus imitating the conditions of traditional batch fermentation $^{2}$. It is believed that the ALR system described in this paper, using a brewing yeast immobilized on the surface of a cellulose based carrier made of spent grains (a brewing by-product), may be a promising alternative to existing continuous beer fermentation systems.

\section{ACKNOWLEDGEMENT}

Financial support from FCT (Fundação para a Ciência e Technologia, SFRH/BPD/3541/2000) is gratefully acknowledged.

\section{REFERENCES}

1. Analytica - EBC, European Brewery Convention, Fachverlag Hans Carl: Nürnberg, 2000, Section 9, Method 9.10.

2. Andries, M., van Beveren, P., Goffin, O. and Masschelein, C., Design of a multipurpose immobilized yeast bioreactor system for application in the brewing process, In Monograph 24, EBCSymposium Immobilized Yeast Applications in the Brewing Industry, Espoo, Fachverlag Hans Carl: Nürnberg, 1995, pp. 134 143.

3. Bonora, A. and Mares, D., A simple colorimetric method for detecting cell viability in cultures of eukaryotic microorganisms, Current Microbiology, 1982, 7, 217-222.

4. Brányik, T., Vicente, A. A., Machado Cruz, J. M. and Teixeira, J. A., Spent grains - a new support for brewing yeast immobilisation, Biotechnology Letters, 2001, 23, 1073-1078.

5. Dömény, Z., Šmogrovičová, D., Gemeiner, P., Šturdík, E., Pátková, J. and Malovíková, A., Continuous secondary fermentation using immobilised yeast, Biotechnology Letters, 1998, 20, 1041-1045.

6. García, A. I., García, L. A. and Días, M., Modelling of diacetyl production during beer fermentation, Journal of the Institute of Brewing, 1994, 100, 179-183.

7. Grönqvist, A., Pajunen, E. and Ranta, B., Secondary fermentation with immobilized yeast - industrial scale, Proceedings of the European Brewing Convention Congress, Zurich, IRL Press: Oxford, 1989, pp. 339-346.

8. Guimarães, C., Matos, C., Azeredo, J., Mota, M. and Oliveira, R., The importance of the morphology and hydrophobicity of different carriers on the immobilization and sugar refinery effluent degradation activity of Phanerochaete chrysosprium, Biotechnology Letters, 2002, 24, 795-800.

9. Hyttinen, I., Kronlöf, J. and Hartwall, P., Use of porous glass at Hartwall brewery in the maturation of beer with immobilized yeast, In MONOGRAPH 24, EBC-Symposium Immobilized Yeast Applications in the Brewing Industry, Espoo, Fachverlag Hans Carl: Nürnberg, 1995, pp. 55-61.

10. Kronlöf, J., Härkönen, T., Hartwall, P., Home, S. and Linko, M., Main fermentation with immobilized yeast, Proceedings of the European Brewing Convention Congress, Zurich, IRL Press: Oxford, 1989, pp. 355-362.

11. Linko, M., Virkajärvi, I., Pohjala, N., Lindborg, K., Kronlöf, J. and Pajunen, E., Main fermentation with immobilized yeast - a breakthrough? Proceedings of the European Brewing Convention Congress, Maastricht, IRL Press: Oxford, 1997, pp. 385394.

12. Linko, M., Haikara, A., Ritala, A. and Penttilä, M., Recent advances in the malting and brewing industry, Journal of Biotechnology, 1998, 65, 85-98.

13. Masschelein, Ch. A., A realistic view on the role of research in the brewing industry today, Journal of the Institute of Brewing, 1997, 103, 103-113.

14. Mensour, N. A., Margaritis, A., Briens, C. L., Pilkington, H. and Russell, I., New developments in the brewing industry using immobilised yeast cell bioreactor systems, Journal of the Institute of Brewing, 1997, 103, 363-370.

15. Pajunen, E., The behaviour of immobilized yeast cells, Cerevisiae, 1996, 4, 33-37.

16. Šmogrovičová, D., Dömény, Z., Gemeiner, P., Malovíková, A. and Sturdík W., Reactors for continuous primary beer fermentation using immobilised yeast, Biotechnology Techniques, 1997, 11(4), 261-264. 
17. Šmogrovičová, D., Dömény, Z., Slugeň, D., Pátkova, J. and Bafrncová, P., Gluten pellets to immobilise yeast for brewery fermentations, Monatsschrift für Brauwissenschaft, 1999, 7/8, $119-122$.

18. Tata, M., Bower, P., Bromberg, S., Duncombe, D., Fehring, J., Lau, V., Ryder, D. and Stassi, P., Immobilized yeast bioreactor systems for continuous beer fermentation, Biotechnology Progress, 1999, 15, 105-113.

19. van Iersel, M. F. M., van Dieren, B., Rombouts, F. M. and Abee, T., Flavour formation and cell physiology during the production of alcohol-free beer with immobilized Saccharomyces cerevisiae, Enzyme and Microbial Technology, 1999, 24, 407411.
20. van Oss, C. J., Hydrophobicity of biosurfaces - origin, quantitative determination and interaction energies, Colloids Surfaces B: Biointerfaces, 1995, 5, 91-110.

21. Virkajärvi, I. and Kronlöf, J., Long-term stability of immobilized yeast columns in primary fermentation, Journal of the American Society of Brewing Chemists, 1998, 56, 70-75.

22. Virkajärvi, I. and Pohjala, N., Primary fermentation with immobilized yeast: Some effects of carrier materials on the flavour of the beer, Journal of the Institute of Brewing, 2000, 106, 311318.

(Manuscript accepted for publication August 2002) 